\title{
Left at Home in Iowa: "Progressive Regionalists" and the WPA Guide to 1930s Iowa
}

\author{
JULIA MiCKENBERG
}

THE CULTURE OF THE 1930s embodied a combination of optimism and despair, expressed in national and local stocktaking, a return to local roots, and a national push toward central planning and control. It was a period of obsessive documenting: photographing drought-stricken landscapes and poor, hungry farmers, recording the stories of coal miners and exslaves, painting the fields and mountains, silos and skyscrapers of America. All of the collection and documentation was undertaken in an effort to get at the "real" America that most people believed was still there, surviving from the past, waiting to be rediscovered and used in this time of crisis. The shared commitment to uncovering an authentic, usable past at times masked conflicting views about the true nature of that past.

I want to thank Jim and Kathleen McGovern, Kathy Luckritz, Jim and Helena Dodds, Mildred Westburg, Bob Kraus, Douglas Wixson, Dan Birkholz, and Marvin Bergman for information, encouragement, and assistance. Thanks especially to Jim Dodds for taking me horseback riding in Algona, Raymond Kresenky's hometown. The State Historical Society of Iowa, with funding from the Iowa Sesquicentennial Commission, provided financial assistance for the research. An earlier version of this paper was presented at Iowa Heritage Expo, June 14, 1996.

1. Warren Susman discusses the search for the "real" America in Culture as History: The Transformation of American Society in the Twentieth Century (New York, 1984), 150-83. See also William Stott, Documentary Expression and Thirties America (Chicago, 1986).

THE ANNALS OF IOWA 56 (Summer 1997). CThe State Historical Society of Iowa, 1997. 
The decade of the $1930 \mathrm{~s}$ is remembered in the national imagination primarily as a time of economic crisis and social and political unrest. But perhaps the most significant legacy of the decade was the government's response to the crisis. That legacy was cultural as well as economic and political. Through the Works Projects Administration (WPA) in particular, the federal government paid writers, artists, musicians, and actors to create history and art from everyday life and landscapes in America. The major achievement of the Federal Writers' Project (FWP), a division of the WPA, was the American Guide series - guidebooks to all fifty states as well as many cities, rivers, roads, and regions. More than a half-century after their publication, the guidebooks are still perhaps the "deepest map" of regional America. ${ }^{2}$

Iowa's WPA guidebook, titled Iowa: A Guide to the Hawkeye State - originally published in 1938 to coincide with the celebration of Iowa's territorial centennial - was reprinted in 1996 in honor of the state's sesquicentennial. It still speaks to contemporary readers with a wealth of details about Iowa's history, agriculture, literature, arts, industry, religion, folkways, and natural setting; it also guides readers through major cities and along roadways, noting landmarks and legends along the way.

Invisible in the book's pages is another story, the story of the book's creation. That story connects New Deal regionalism to an independent, Popular Front-inspired regional literary movement and to a little magazine, Hinterland. The connection was marked by overlapping personnel and, to a certain extent, overlapping interests. But it also reflected tensions and different visions of Iowa. ${ }^{3}$

2. The concept of a "deep map" comes from William Least Heat Moon, PrairyErth (a deep map) (Boston, 1991).

3. Other historians have seen the American Guide series in the context of Popular Front democratic nationalism and have linked it to broader cultural currents such as regionalism and the elevation of "the folk." See, for example, Charles Alexander, Here the Country Lies: Nationalism and the Arts in TwentiethCentury America (Bloomington, IN, 1980); and Warren Susman, "The Thirties," in Stanley Coben and Lorman Ratner, eds. The Development of an American Culture (New York, 1970), 245-46. But scholars have not focused on the link between regionalism as an independent literary movement and the regional programs of the New Deal arts projects, particularly the Federal Writers Project. 
The rich portrait that emerged in the Iowa guidebook grew out of a compromise between a federal blueprint that constructed Iowa as a piece in a national puzzle and the deeply personal, sometimes politicized feelings about the state among some guidebook writers. The writers generally welcomed advice from the staff of the State Historical Society of Iowa (people who knew Iowa intimately); counsel from Washington, meanwhile, was begrudgingly heeded, indicating that deeply held regionalist convictions of the 1930s extended into and influenced the production of the American Guide series.

Exploring the dynamics of the context out of which the Iowa guidebook emerged dispels the mystique of the book's anonymous, collective authorship, explains the poetry of many of its passages, and suggests why members of the Federal Writers' Project in Iowa found it difficult to write about the state from a Washington-generated blueprint. At a broader level, such an exploration yields a telling portrait of intellectual and cultural currents in Iowa in the late 1930s, and provides a concrete example of the FWP's relationship to a particular regionalist movement and community.

THE WPA "FEDERAL ONE" ARTS PROGRAMS, which included the FWP, were designed primarily to provide meaningful relief work for artists and professionals who had lost their jobs and their job prospects during the depression. The arts programs were also envisioned as a way to build a more democratic public culture and to foster the creation of a genuinely American art that would incorporate a patchwork of American landscapes, history, and myths. ${ }^{4}$

While artists, musicians, and actors pursued creative projects under the WPA, projects for writers took the longest to initiate. Even when funds were allocated for a Federal Writers' Project,

4. See William F. McDonald, Federal Relief Administration and the Arts: The Origins and Administrative History of the Arts Projects of the Works Progress Administration (Columbus, OH, 1969); Paul Sporn, Against Itself: The Federal Theater and Writers' Projects in the Midwest (Detroit, 1995); and Kenneth J. Bindas, All of this Music Belongs to the Nation: The WPA's Federal Music Project and American Society (Knoxville, TN, 1995). 
administrators felt that it was unwise to give total creative freedom to writers because many young intellectuals had become radicalized by the economic devastation of the depression and some were sympathetic to Communist and other left-wing movements. Some government officials believed that writers, if given a free hand, would create revolutionary tracts with funding from the very government they wished to overthrow. ${ }^{5}$

The American Guide series, with its standardized format and careful supervision, seemed like a safe and valuable project for writers to undertake: writers could learn more about their native regions and share what they learned with the public without much opportunity to inject subversive ideology into the writing. Henry Alsberg, the head of the FWP, conceived of the WPA guidebooks as "a discovery of the roots from which America had grown and a signpost of America's potentialities for the future." ${ }^{\prime 6}$ By emphasizing folklore, regional differentiation, and the contributions of minorities, including African Americans and other ethnic and racial groups, the guidebooks' designers hoped to build national pride and a respect for American cultural diversity.

Such a democratically based cultural nationalism appealed to many left-wing intellectuals and artists, nationally and in Iowa. A fair number of them strongly supported President Roosevelt and the New Deal, even though New Deal programs were clearly enacted to preserve the existing system rather than to revolutionize it, and creative projects under the New Deal could only go so far in critiquing social and economic conditions. But be-

5. For the government's anxiety about allowing creative freedom to rebellious young writers, see Jerre Mangione, The Dream and the Deal: The Federal Writers' Project, 1935-1942 (New York, 1972), 241-43. For other works on the FWP, see Monty Noam Penkower, The Federal Writers' Project: A Study in Government Patronage of the Arts (Urbana, IL, 1977); and Jerrold Hirsch, "Portrait of America: The Federal Writers' Project in an Intellectual Context" (Ph.D. diss., University of North Carolina at Chapel Hill, 1984). On the Iowa Writers' Project, see John Edward Westburg, "Essay on Raymond Kresensky: The Poet and His Endeavors," in The Complete Poems of Raymond Kresensky, vol. 1 (Fenimore, WI, 1986), xvi-xxi; Don Farran, "The Federals in Iowa: A Hawkeye Guidebook in the Making," Annals of Iowa 41 (1973), 1190-96; Joseph Frazier Wall, "Introduction," The WPA Guide to 1930s Iowa (1938; reprint, Ames, 1986), xi-xix.

6. McDonald, Federal Relief Administration and the Arts, 665. 
cause federal support for the arts on the scale of the WPA was unprecedented, left-wing writers, artists, and intellectuals, who saw the great potential in the WPA arts programs, accepted (sometimes begrudgingly) their limitations. The FWP's program of documenting American regional diversity, with its emphasis on uncovering the stories of underrepresented ethnic groups, workers, and "folk," linked the interests of the left, federal and state governments, and certain regionalist literary movements. ${ }^{7}$

Regionalism as a literary and cultural program is not generally associated with movements for social change, but in the late 1930s a number of self-identified regionalist writers, particularly in the Midwest, joined the Popular Front, a coalition of left-liberal organizations devoted to opposing the threat of international and domestic fascism. Writers who called themselves "progressive regionalists" were one faction of a broad and relatively unconnected group of regionalist movements, most of which blossomed in the late teens and early twenties. In Tennessee, the "Southern Agrarians," centered around Vanderbilt University, insisted that the southern way of life was being encroached upon by the cultural, economic, and political dominance of the industrial Northeast. In the Midwest, regional artistic and literary movements initially took root as writers and artists sought to explore their native regions, working also to create an American literature free from the domination of publishing interests and cultural understandings in New York. John T. Frederick's little magazine Midland, established in Iowa City in 1915, operated on the philosophy that "serious writers should remain in their native regions where they might develop their art unfettered by the standardizing and commercializing influences of New York." Their literature, he hoped, would use material from their own region to express "the native, natural and genuine, not the remote, external and artificial."

7. For the limitations on the Federal One arts projects, see Bindas, All of this Music Belongs to the Nation, vii.

8. Quote from Milton M. Reigelman, The Midland: A Venture in Literary Regionalism (Iowa City, 1975), 45. On the Southern Agrarians, see I'll Take My Stand: The South and the Agrarian Tradition, by Twelve Southerners (New York, 1930). On the regionalist impulse in the 1920 s and 1930s, see Robert L. Dorman, Revolt of the Provinces: The Regionalist Movement in America, 1920-1945 (Chapel Hill, NC, 
Frederick did not introduce regionalism to Iowa; rather, he provided a vehicle for a movement that was already blossoming through the works of Hamlin Garland, Johnson Brigham, and Thomas Herringshaw, who established a tradition of Iowa regionalism in the 1890s. But in the 1920s Iowa artists and writers such as Grant Wood, Ruth Suckow, and Jay Sigmund began to attract national attention to the regionalist movement. Despite a thriving tradition of regional writing, it was still difficult for Iowa writers to stay in Iowa and make a living as writers. It was no coincidence that so many famous Iowa writers - Paul Corey, Josephine Herbst, Ruth Lechlitner, Phil Stong, Ruth Suckow, and others - went east to find success. They also went east to join a community of other writers, since many writers from the "hinterland" felt like isolated renegades whose work was devalued in their native communities. As one former Project worker put it, "in Iowa, as in most of the agricultural states, to most a fine pig was more important than a fine poem." ${ }^{\prime \prime}$

Contrary to such sentiments, the hinterland actually came into vogue in the 1930s, injecting the regional art and literary movements in Iowa with a new vitality. Warren Susman claims that while "the 1920s found intellectuals in revolt against the village; the 1930s witnessed the intellectuals in flight to the village." Rather than rejecting America as cultureless (as a number of $1920 \mathrm{~s}$ expatriate intellectuals had done), intellectuals in the 1930 s became deeply interested in discovering the "real" America. The economic climate of the 1930 s made the virtue a necessity. Iowa writers who might have gone east in an earlier time now had no choice but to stay home. As a result, pools of talent collected in Des Moines, Davenport, Cedar Rapids, and Iowa City. The Federal Writers' Project, initiated in 1935, supported this home-

1993); Michael C. Steiner, "Regionalism in the Great Depression," Geographical Review 73 (1980), 430-46; John L. Thomas, "The Uses of Catastrophism: Lewis Mumford, Vernon Parrington, Van Wyck Brooks, and the End of American Regionalism," American Quarterly 42 (1990), 223-51; and Wanda Corn, Grant Wood: The Regionalist Vision (New Haven, CT, 1983). The work that links strands of regionalism to midwestern radicalism is Douglas Wixson, WorkerWriter in America: Jack Conroy and the Tradition of Midwestern Literary Radicalism, 1898-1990 (Urbana, IL, 1994). For regionalism in Iowa, see E. Bradford Burns, Kinship with the Land: Regionalist Thought in Iowa, 1894-1942 (Iowa City, 1996).

9. Burns, Kinship with the Land, 18-24, 44, 130-61; Westburg, "Raymond," vii. 
grown talent by providing funding for writers to explore and document their native regions. ${ }^{10}$

The vogue of the village was also a boon to regional writing and regionalist little magazines. ${ }^{11}$ Frederick's Midland inspired other writers and editors in Iowa to create more little magazines focusing on the work of midwestern writers. Influenced by the radical cultural movements of the 1930s, little magazinesincluding Hub, Hinterland, Left, and The Dubuque Dial in Iowa, along with Jack Conroy's Anvil in Missouri, Midwest in Minnesota, Left Front and the New Quarterly in Illinois, and a smattering of others across the Midwest-helped foster interconnected regional communities that were united by "the conviction that a new radical consciousness, distinctly midwestern in character, was in the making. ${ }^{\prime \prime 2}$

The coalition building that characterized the Popular Front in the second half of the 1930s inspired writers to organize. "Progressive" (that is, antifascist, pro-labor, and pro-New Deal) writers from across the country gathered at regional conferences modeled on the national meetings of the anti-fascist League of American Writers, held in the late 1930s and early 1940s. In the Midwest, writers coalesced around a program they called "progressive regionalism." That program linked indigenous traditions of protest, such as populism, Debsian socialism, and the Non-Partisan League, with a tradition of regional writing found in the works of Hamlin Garland, Herbert Quick, Sherwood Anderson, and others who focused on the struggles of common people in small towns and on farms. In the face of domestic and

10. Susman, "The Thirties."

11. The term little magazine came into vogue in the 1920s. It referred to magazines "designed to print artistic work which for reasons of commercial expediency is not acceptable to many money-minded periodicals or presses." Little stood for the magazine's limited readership, rather than its physical size; it also, as Milton M. Reigelman points out, "reflect[ed] a conscious opposition to the standards of the big magazines." Regionalist little magazines worked to shift the basis of American literary output away from New York and publish the work of lesser-known writers, who often hailed from rural areas or small towns. Frederick J. Hoffman, Charles Allen, and Carolyn F. Ulrich, eds., The Little Magazine: A History and Bibliography (Princeton, NJ, 1946), 2-3; Reigelman, The Midland, xii.

12. Wixson, Worker-Writer in America, 317, 314. 
international fascism in the late 1930s, the Midwest's heritage of struggle and its literary representation was expanded to encompass the need for broader commitments and concerted action. In Iowa, writers and researchers working for the FWP joined together with independent writers to form the Midwest Literary League, which encouraged regional writing and advocated progressive causes ranging from federal support for the arts to farm aid. The group also collectively edited and published a progressive regionalist little magazine, Hinterland. Through poetry, fiction, and essays, Hinterland depicted a view of Iowa and its people that was implicated in, but largely absent from, the WPA guidebook's "deep map" of Iowa. ${ }^{13}$

THE MIDWEST LITERARY LEAGUE was the brainchild of Iowa writer Raymond Kresensky, who came up with the idea for the league in the spring of 1936, just after he had begun his job as editor of Iowa's WPA guidebook. He eventually became director of the FWP in Iowa, taking over from Jay Du Von in the spring of 1937, when Du Von became the director of the FWP in Illinois. Most of the core members of the Midwest Literary League were editors and writers on the Iowa guidebook, but more than any other individual, Raymond Kresensky linked the FWP in Iowa to a wider community of writers and to a blossoming literary movement. ${ }^{14}$

13. Ibid., 149-50. The Midwest Literary League allied in the summer of 1936 with the Midwest Federation of Arts and Professions, an umbrella progressive regionalist group that published Midwest magazine. See Midwest (A Preview of a Review), August 1936,1-2. Seven delegates from the Midwest Literary League attended the Midwest Writers' Congress in Chicago, which resulted in the formation of the Midwest Federation of Arts and Professions and Midwest Magazine. Hinterland, 2d ser., 1 (September 1936), 28. For more on the Midwest Federation of Arts and Professions, see Minutes, Midwest Federation of Arts and Professions, Chicago, June 1936 (in author's possession, courtesy of Douglas Wixson).

14. In the "Preview" issue of Midwest (August 1936), Dale Kramer described the origins of the Midwest Literary League, noting Kresensky's role (1). This background on the League is not meant to suggest that the majority of workers on the FWP in Iowa were involved with the League or with the production of Hinterland. But those who were involved tended to be in positions of leadership in the Des Moines office, and they may have influenced other workers to become involved in one form or another. Many workers, of course, saw the FWP as little more than a way to put bread on the table. 
Kresensky was born and raised in the farming community of Algona and attended Coe College and McCormick Theological Seminary. He had been a minister, teacher, and sometime hobo. As he told one magazine editor, "[I] have lived in many, many towns, am quite a traveler, and have bummed on a freight train. I am a socialist, interested in farm problems, single, an individualist, a hedonist, and a passionate devote [sic] of the lost art of conversation." Before getting work with the FWP as the guidebook editor, Kresensky had published a book of poems, Emmaus. His poetry, infused with religious imagery and often focused on the plight of midwestern farmers, had been published in the New York Times, Midland, Commonweal, Poetry, The New Masses, and many other magazines. Kresensky's poetic sensibilities and strong feelings for the state and its people were responsible for the high quality of both Hinterland and the WPA guidebook. ${ }^{15}$

In 1936, however, Hinterland was struggling under Dale Kramer's leadership. Kresensky, who had been a frequent contributor to the little magazine, figured that with some staff support, machinery, and supplies from the FWP, helped along by contributions from sympathetic individuals who would join the league, Hinterland could get a new lease on life. The new Hinterland, to be published cooperatively by the Midwest Literary League, would showcase the best in midwestern writing and would advocate progressive causes on a regional and national level, including support for the FWP. ${ }^{16}$

15. Kresensky to William Kelm, n.d:, box 12, Karlton Kelm Papers, Special Collections, University of Iowa Libraries. Despite calling himself a "socialist" here, on another occasion Kresensky responded to suggestions on a story he'd written for the Dubuque Dial, saying, "Your suggestions were good but then I didn't intend to make a revolutionary story out of it. God, I'm not bound to any Marxian theories or systems!" Kresensky to Karlton Kelm, 3 December 1934, box 8, Karlton Kelm Papers.

16. Hinterland was the longest-running regionalist literary magazine published primarily by FWP members, and it was an outstanding one. Hoffman, et al., eds., Little Magazine, 320. FWP workers in San Francisco produced a mimeographed booklet in 1936, which included an anonymous "Marxist-minded" essay, "The Possibilities of an Intelligent Regionalism in California," but otherwise showed few radical tendencies. The same year the Nebraska Writers' Project also published a booklet of its writers' creative work called "Shucks." The San Francisco writers also printed one issue of The Coast. See Mangione, The Dream and the Deal, 241-43 (which does not mention Hinterland). 
A flier sent out to writers and editors around the Midwest encapsulated the league's mission and the tenor of work that would be printed in Hinterland. The league aimed to support a locally grounded but broadly committed midwestern literary movement that responded to contemporary social, political, and economic conditions. "Its purposes," the flier claimed,

are to bring about an increased awareness of the regional, agrarian basis of our 'culture' and the identity of our interests as writers with that economic background. It is upon our conscience as writers - as the articulate and sometimes forewarned conscience of the people of whom we are a part, to fight against every attack which is made upon it, either through war, for which we can recognize no possible justification, or through fascism which is opposed to everything we believe in and respect. ${ }^{17}$

The league's antifascist position and even the Marxist sympathies of some contributors (most evident in the book reviews) did not make the league a Communist organization by any means. The red-baiting of the McCarthy era has obscured the complexity and variants of people's sympathies and commitments during the 1930s. In the spring of 1936, when the league was organizing and sending out fliers, Franklin Roosevelt's administration had come out in opposition to fascism, so an antifascist political bent could be seen as an expression of patriotic Americanism. But more than anything else, Hinterland

17. Midwest Literary League (temporary committee) to Karlton Kelm, n.d. [1936], box 11, Karlton Kelm Papers. See also Hinterland, 2d ser., 1 (September 1936), 1-2. The league's letter did not mention the FWP or the WPA, but anyone familiar with the FWP would have known the people on the "temporary committee" listed on the letterhead: Raymond Kresensky, a reasonably wellknown poet and editor of lowa's WPA guidebook; Jay Du Von, poet, former editor of the little magazines Left and New Quarterly, and the FWP director in Iowa; Ruth Stewart, a former secretary of the Iowa author's club and FWP supervisor; Opal Shannon, a published poet and tours editor on the guidebook; Mary Hudson, an FWP editorial assistant; and William Pillin, an itinerant left-wing poet who was an FWP staff writer and active in the Iowa Writers' Union. The only two members of the committee not associated with the FWP were Dale Kramer, a farm advocate and editor of the original Hinterland (who became coeditor of Midwest); and Roland White, a student at the University of Iowa who had been editor of the university's literary magazine. Dale Kramer to Karlton Kelm (mentions Ruth Stewart and Roland White), n.d., box 11, Karlton Kelm Papers. 
focused on the everyday struggles of farmers and townspeople in the Midwest, and its contributors attempted to show the poetry of common people's lives. To some extent, the guidebook did that as well; that is, it elevated the common and everyday to the status of history. ${ }^{18}$

For many idealistic young writers, then, the Midwest Literary League's mission seemed to complement that of the Federal Writers' Project. Several months before Hinterland got under way, Iowa director Jay Du Von had proudly told Washington administrators that several of the field workers were regularly selling material based on guidebook research, "and others have embarked on more ambitious projects: stories, poetry, novels, which have as their background a regional awareness developed through the guide." If connecting work on the guidebook to such personal pursuits was praiseworthy, creating a magazine that continued to foster this "regional awareness" ought to be even better. It would allow the writers to feel that their talents were really being utilized, and the magazine would show the public that the Projects were actually producing something, since it was taking so much longer than planned to get the guidebooks out. ${ }^{19}$

Without consulting officials in Washington, FWP workers in lowa started producing Hinterland, using a press in the FWP's office in the old Federal Building in Des Moines. Two FWP workers spent about ten work days (on Project time) setting type. FWP workers in Iowa wrote approximately two-thirds of

18. Some Hinterland book reviews that demonstrate such sympathies are reviews by Michael B. Scheler of Russia-U.S.S.R and The Soviet Union Today, both edited by P. Malevsky Malevitch, 2d ser. 2, no. 3 [1938?], 52, 54; and Norris Getty's review of Edwin Seaver's Between the Hammer and the Anvil, 2d ser. 1, no. 4 [1937?], 122-23. A kind of populist anticapitalism is more evident than Marxism; see, for example, Ruth Wolcott's poem, "Capitalism," 2d ser. 2, no. 3 [1938?], 33; and Opal Shannon, "Folk Moot," 1st ser. 1, no. 4 (January 1936), 6.

19. Jay Du Von to Henry Alsberg, 16 March 1936, Editorial Correspondence, 1936-39, box 14, Records of the Central Office, Iowa Records of the Works Projects Administration, Records of the Federal Writers' Project, RG 69, National Archives, Washington, DC (hereafter cited as Editorial Correspondence, FWP Records, NA). Du Von noted that "lack of some adequate form of tangible publication has been one of the points on which the Writers' Project has received the severest criticism." Du Von to Alsberg, 22 August 1936, ibid. 
the material in the first issue, which included the editorial mission of the magazine; poems by James Hearst, Marion Louise Bliss, Lee Grove, Opal Shannon, Thomas M. Duncan, William Pillin, and Raymond Kresensky; fiction by Jay Sigmund, William Carl Smith, and George Nicholson; and prints by John C. Rogers and Polia Pillin. The opening editorial explained that "the League is a co-operative venture, taking from each according to his ability." But allusions to Marx (and even Marxist sympathies) did not translate into hardline ideology, as indicated by Robert Travers"s "Wanderlust," a spoof on goose-stepping "fellow travelers," which was also in the first issue. The issue also included a long piece on the Federal Writers' Projects, focusing in particular on the American Guide, and it urged support for the WPA arts projects. ${ }^{20}$

The writers' strong support for the WPA and the FWP obscures a conflict between FWP officials in Washington, DC, and FWP workers in Iowa over production of the Hinterland. Iowa FWP director Jay Du Von himself acknowledged that the plan to use FWP time, workers, and machinery, was "not strictly in order," but believed that it "was well within the intent and purposes of the project." When Du Von belatedly informed federal officials of what was going on, though, they halted production of the first issue of Hinterland, telling $\mathrm{Du}$ Von that if writers wanted creative outlets there would soon be a national literary magazine showcasing FWP writers' work (a promise that was never really fulfilled). Despite initial hopes in Iowa that a regional magazine would "provide a medium for the publication of creative work by project workers and others, ... give practical experience in editing and publishing to project workers, . . . and raise the morale of the workers who feel that something tangible, creative and important is to come out of their organization," Washington administrators made it clear that a "progressive regionalist" little magazine had no place drawing on FWP equipment and personnel. New

20. Information about Hinterland in Du Von to Henry Alsberg, 22 August 1936, box 14, Editorial Correspondence, FWP Records, NA. Du Von also included copies of several pages of the magazine to show Alsberg and others something of its tenor and quality. 
Deal regionalism, despite all its "progressive" qualities, did not go that far. ${ }^{21}$

Hinterland managed to continue publication without FWP assistance, but frequent reviews of FWP publications and advocacy of WPA arts projects suggested that the magazine's editors continued to see Hinterland and the WPA as related enterprises. Nonetheless, the failed attempt to make Hinterland an FWP publication (officially or unofficially) demonstrated real disparities in understanding between state projects and the national administration as to the FWP's purpose and parameters.

FOR KRESENSKY and his staff of writers and researchers, the Hinterland incident was an early indication that the Federal Writers' Project would not be the panacea that many writers had hoped for. Low morale following the Hinterland mishap got even lower when the federal government made the first cuts in the FWP budget in the fall of 1936. Cuts meant layoffs, and the layoffs brought a storm of protest. ${ }^{22}$

21. Official policy held that no creative work was to be undertaken on Project time by individual FWP writers (or groups of writers) without explicit permission from the national office. After Washington administrators learned about Hinterland, they forbade the FWP staff from using Project time or equipment to produce the magazine. They insisted that the only way Hinterland's first issue could be published was if it was completed after hours and distributed without cost, with full credit going to the FWP. Later editions would have to be compiled entirely independently of the FWP. Du Von decided it was best to keep it a secret that the magazine ever had any connection to the FWP, and somehow he managed to convince Washington to let the first issue get published, with no mention in the magazine of the aid it had received from the FWP. Du Von expressed regret for failing to inform his superiors about what was happening, but he was also disappointed that the government could not see the value of the League's undertaking. See Reed Harris to Du Von, 20 August and 11 September 1936, and Du Von to Henry Alsberg, n.d. (received 17 August), 22 and 24 August 1936, box 14, Editorial Correspondence, FWP Records, NA. American Stuff was meant to be a magazine for FWP writers, but was published instead as a one-volume compilation of creative work by FWP workers. Mangione, The Dream and the Deal, 240-55.

22. See telegrams sent from the lowa Local American Writers' Union to WPA director Harry Hopkins, 23 July and 15 October 1936, box 1339, "State" Series, 1935-1944, Professional and Service Projects, Writers' Program, WPA Central Files, RG 69, National Archives. 
One of those cut from the Iowa Project was writer William Pillin. Pillin, in some ways, embodied the rift between writers and administrators. Although he had applied for a job when the FWP was initiated in Iowa, he was hired on the lowa Writers' Project only after he appealed directly to Henry Alsberg, claiming that he was more qualified than some other workers on the project who could barely call themselves "writers." Pillin hoped that the American Guide series would set a precedent for a much larger program of government-supported arts. He advanced this notion as a member of Hinterland's editorial board and as a contributor, suggesting that readers join in the movement to form a "National Academy of Arts and Letters," which would extend the WPA arts projects by funding creative work by the nation's best artists and writers. Pillin thought guidebook writing was worthwhile, but did little to develop writers' creative potential. "The finest minds in America agree that unless something is done for the writers, literature will degenerate into a mere clever pastime." According to FWP administrators, Pillin took matters into his own hands, devoting considerable energy to his own creative projects at the expense of work on the guidebook. That, they said, helped get him fired. ${ }^{23}$

Whatever the reason for Pillin's firing - and it is not clear from the documentary record-his dismissal unleashed a fury that brought attention to the Iowa Writers' Project from writers and artists across the country. In Chicago, five hundred WPA workers assembled to protest Pillin's dismissal. The Artists' Union of Chicago blamed Du Von for Pillin's dismissal, sug-

23. Pillin to Alsberg, 3 February 1936, box 13, Editorial Correspondence, FWP Records, NA; William Pillin, "The National Academy of Arts and Letters," Hinterland, $2 \mathrm{~d}$ ser. 1 (October-November 1936), 49. Pillin was not alone in hoping that the FWP would do more than fund guidebooks. Don Farran, president of the Iowa Authors Club and later an FWP staffer, had written to WPA director Harry Hopkins asking that the FWP support Carroll Coleman's Prairie Press, a small press devoted to small-run, high quality publications featuring Iowa writers. Wasn't preserving the best work in the state part of the IWP's mission? asked Farran. His request was courteously rejected, with the explanation that such projects fell outside the rubric of federal programs. Farran to Harry Hopkins, 14 December 1935, box 1, Editorial Correspondence, FWP Records, NA. 
gesting that Du Von was hostile to the Writers' Union, with which Pillin was involved. Poet $\mathrm{H}$. H. Lewis of Missouri condemned Du Von's hypocrisy, accusing him of giving in to redbaiters and of persecuting "good union folks." Other letters came from writers and artists in Iowa and across the country, bringing enough support for Pillin that he was offered a job on the FWP in Illinois, where Du Von would soon become director, passing his Iowa position on to Kresensky. Although Washington administrator Reed Harris tried to assure protesters that Pillin's dismissal had nothing to do with his union activity, and that "Mr. Du Von has extended every possible consideration to the union at all times," Pillin's dismissal and the ire it raised certainly affected the morale of FWP workers in Iowa. Pillin also resigned from Hinterland's editorial board after the incident and stopped contributing to the magazine. ${ }^{24}$

The Pillin controversy illustrated both the creative and political tensions within the FWP. Project administrators were willing to support writers' creative activity to a point, but not if they thought it interfered with the Project's goals. On the political level, the controversy had the potential to damage the Project's public image in the same way that politicized copy in the guidebooks could bolster claims that the Federal One arts projects were controlled by unpatriotic radicals. Yet it quickly became apparent that most participants in the Writers' Project in Iowa, while politically committed, were by no means revolutionary. Producing a true-to-life portrait of Iowa proved to be of greater interest than overthrowing the government, even though the "true" Iowa was a matter of some contention. ${ }^{25}$

24. Reed Harris to Mark Thompson, 9 January 1937, and Reed Harris to H. H. Lewis, December 1936, box 13, Editorial Correspondence, FWP Records, NA. See also other correspondence from the same folder, all dated December 1936.

25. John Edward Westburg, an FWP worker from 1938 to 1940, acknowledged that the well-educated FWP workers who were suffering under the effects of the depression were, not surprisingly, often "highly critical of the existing order of society." But, he said, there were few real Communists. He did note Kresensky's skill at finding "better" jobs for troublemakers on staff. Westburg actually suspected that Communists were brought in from New York to sabotage the FWP and discredit the WPA so that lingering unemployment would expedite revolution. Westburg, "Raymond," xviii. 
THE FEDERAL WRITERS' PROJECT had been criticized publicly because of a common belief that the Projects harbored a bunch of radicals. The Des Moines Register, for example, announced Jay Du Von's appointment to the Writers' Project in the fall of 1935 with the headline, "Leftist Poet Named to Iowa WPA Post." But the Projects also came under fire because they seemed incredibly unproductive, the "arch boondoggle" of the WPA. With thousands of writers and researchers employed across the country in the task of writing state guidebooks, there was very little, at least for the first year or so, to show for their efforts. ${ }^{26}$

There were a number of reasons why the guidebooks took so long to get published. First was the very nature of the project, which involved combing through a mass of widely dispersed material, conducting interviews, and visiting sites, all with a limited number of relief personnel who often had questionable qualifications and limited interest in their work. After material was collected, it had to be written into tours and essays that conformed to federally established guidelines. All written work required input from several consultants and, once drafted, the approval of the in-state sponsors and the Washington editors and administrators. ${ }^{27}$

Despite the challenges of the operation, Raymond Kresensky, as the guidebook's editor and later as Project director, tried to remain optimistic, reminding himself and others that both the guidebook and its mode of production were of historic importance. "The writing here is rather 'socialized,' or 'collectivized,'" Kresensky said of work on the guidebook. "That is, two or three writers add their bit, then we hear from consultants, and then

26. Des Moines Register, 14 October 1935. According to an article in Time, 3 January 1938, 55, nine months after the Project got underway there were 6,000 employees nationally on the FWP payroll. By 1938 there were 3,000 , of whom 1,200 were writers, as distinguished from research workers or office assistants.

27. The Writers' Projects were officially inaugurated on 27 July 1935, but the first state guidebooks were not published until 1937. Some city and local guidebooks were published as early as 1936. Iowa's guidebook was not published until August 1938. More than 49 consultants regularly advised the FWP staff in Iowa; many others were called upon once or occasionally. See Raymond Kresensky to Ethel Merton, 29 December 1937, Federal Writers' Project files, Society Archives, State Historical Society of Iowa, Iowa City (hereafter cited as FWP files, SHSI). 
maybe the Washington office adds its bit, and, maybe, the whole thing starts the rounds again. This is a new venture in writing, I assure you, and something that really should prove to be honest and vital. If it doesn't work, then . . . it doesn't work. ${ }^{\prime 28}$

Despite such expressions of optimism, Kresensky often found it difficult to cope with the bureaucratic procedures. The burden of bureaucracy combined with detailed writing and research instructions made demands for spontaneous, lively writing especially difficult to fulfill. Although all state guides had a similar structure and were written according to the same general guidelines, Washington editors made a point of emphasizing that the writers' chief task was to show what distinguished each locale mentioned in their state's guidebook from every other place in the world. Writers were instructed to pay special attention to "legendary elements" and "the peculiar local color of the environment." State editors and staffers were repeatedly reminded that the goal of the American Guide series was "primarily to introduce Americans to their own rich culture." Therefore, the guides' writers must "seek to point out what is unusual about a city, town or section, rather than what that city, town or section has in common with the majority of others." Writers were urged to avoid boosterism, and told that they should, without bias, portray labor conflict, racial tensions, and other factors that had played a part in the state's development. But in an effort to avoid the appearance of bias, some of those contentious subjects were not treated as extensively as they might have been. ${ }^{29}$

The content and style of the tours and city sections of the guidebook were the earliest sources of contention and criticism from Washington. Alsberg asked for tours that were more revealing than the ones the Iowa office was sending in. "I should

28. Westburg, "The Life and Poetry of Raymond Kresensky," The North American Mentor Anthology of Poems (Conesville, IA, 1965), 12; Kresensky to Ruth Gallaher, 5 February 1937, FWP files, SHSI.

29. Supplementary Instructions \#2, American Guide Manual, "Collection of Data and Classification of Guide Topics for the State Guidebook," 10 December 1935; Supplementary Instructions \#9-A to American Guide Manual (replacing Part A of \#9, 12 March 1936), Folklore and Folk Customs, 27 July 1936; Supplementary Instructions \#15, material for City Guides, boxes 1 and 3, Manuals and Instructions, 1935-1939, FWP Records, NA. 
like to see more visual description of the towns, settlements and countryside and something on the life of the people who now live in these towns - also more on their history," Alsberg instructed. "There is hardly any place that has not had some colorful incident in its settlement or later period," he wrote. "Even the most unimportant and uninteresting town may have a story on how it received its name, why people selected it for their homesite, why it has two Methodist churches instead of one." Alsberg also wanted to know more about "the desires and interests of the people living in the towns" along the tours. "A tour description in Iowa," he insisted, "should help make understandable the life of Iowans who retire to California, why Iowans take to the Townsend movement, and so on." ${ }^{\prime 30}$

After a year of repeated revisions of the tours and cities, Alsberg told Kresensky that these sections of the guidebook were still lacking. "We feel," he said, "that you have mastered the purely formal aspects of the city treatment but that all the liveliness has been squeezed out in the process." With pressure from the sponsors to get the guidebook out as soon as possible (they wanted the book published in early 1938 for the state's territorial centennial), all the delays and calls for rewriting and revision made it seem at times as if the guidebook would never be finished, as if this experiment in collective writing just wasn't working. But by early November 1937, upon approving the final tour manuscript dummy, Alsberg sent Kresensky (now officially the FWP director in Iowa) a note acknowledging all the difficulties that had been involved in the writing and praising the hard work that had "turned utterly lifeless and dull tours into interesting copy." ${ }^{\prime 31}$ The road to such praise had been arduous, but

30. Alsberg to Du Von, 24 and 22 August 1936, box 14, Editorial Correspondence, FWP Records, NA.

31. Alsberg to Kresensky, 1 September and 6 November 1937, box 14, Editorial Correspondence, FWP Records, NA. Kresensky wrote to Benjamin Shambaugh, superintendent of the State Historical Society, trying to explain why progress was so slow. "Our central office is a 'stickler' for form and authenticity.... the check and recheck is wearing, of course, but it will react to a good book." Kresensky to Shambaugh, 3 June 1937, FWP files, SHSI. Kresensky went as far as asking Washington editors whether his staff's work was "up to standard." Kresensky to Cronyn, 1 October 1937, ibid. 
the final product contained the color that the Washington office had been calling for. And the material had been found in locations that may have had personal resonances for the Iowa researchers and writers as well as their readers.

In the final tour copy as it is published in the guidebook, vivid images of Iowa life appear at odd intervals. In the midst of tour 6, which followed U.S. 169 from the Minnesota border to the Missouri border, for example, a description of a church supper follows immediately after a short description of Burt (population 580). Several paragraphs of lively description note the attractive young girls serving as waitresses, the table settings and decorations, the pickles and preserves on every table - and, of course, the food and the rituals of consuming it. Other tours mention points of interest (such as Herbert Hoover's boyhood home in Hubbard or Our Lady of Grace Grotto in West Burlington ["small donation expected"]), celebrations (such as Tulip Day in Orange City and Sauerkraut Day in Ackley), place name origins (Clarinda was named after "beautiful Clarinda Buck, a girl popular among the early settlers"), and legends (an Indian girl was said to have jumped from a high bluff into the Maquoketa River when she fell in love with a white engineer rather than the Indian her father had chosen for her). The wealth of detail did, in fact, make Iowa's small towns seem quite interesting. ${ }^{32}$

The well-earned praise for the tours must have come as a great relief, but Kresensky had developed thick skin when it came to Washington, and he had found an ally in Ruth Gallaher, editor at the State Historical Society of Iowa, which eventually agreed to sponsor the guidebook. By early 1937, with the tours largely complete, Kresensky had begun to use Gallaher as the primary consultant for the essays. Gallaher was a thorough reader and let few mistakes slip by, but she always buttressed her criticisms with encouragement and praise, which made Kresensky keep coming back to her with more essays. Kresensky matched Gallaher's praise with repeated expressions of gratitude and occasional excuses for the errors Gallaher found. "I am sure you

32. Federal Writers' Project of the Works Progress Administration for the State of Iowa, The WPA Guide to 1930s Iowa (1938; reprint, Ames, 1986), 398-400, 383, 522-23, 422, 543, 338. 
understand the job we have," he wrote upon receiving a long list of corrections. "Three or four of us who have had some editorial, literary or journalistic experience and have always 'loved' the state of Iowa want to portray it honestly, but we have the 'dead weights' of a relief proposition, much red tape, temperamental (artistic, they call it) differences, and not a little politics." ${ }^{\prime 33}$

Generally, Gallaher checked the pieces Kresensky sent her for content, and Washington editors critiqued the style, although occasionally they would offer suggestions about the content. Editorial correspondence between Kresensky and Gallaher and between Kresensky and Washington readers such as Alsberg and Cronyn illustrates the triangulated dynamic between the FWP's Des Moines office, the State Historical Society in Iowa City, and the national FWP offices in Washington, DC. The need to incorporate so many voices and satisfy so many people created many difficulties. Comparing the final guidebook copy to sections of Hinterland demonstrates that the guidebook necessarily omitted certain perspectives. As Kresensky put it, "I doubt if Iowa is yet ready for an authentic story ... but our work will be a contribution toward the final thing. We hope that the Guide will rouse interest and thus others will contribute their share toward the approach to the final authentic story. ${ }^{134}$

COMPOUNDING ALL THE DIFFICULTIES of telling an "authentic" story was Kresensky's suspicion that people in Washington didn't really know the first thing about Iowa. He thought that many of the Washington editors' suggestions regarding content were off base. For the "Sports and Recreation" essay, for example, Washington editors suggested treating what seemed like elite activities, and Kresensky responded, with some annoyance, "although croquet and other lawn sports may be the pastime of a few in select circles, they certainly are not common." But Kresensky liked an editor's suggestion that beer drinking might be a popular pastime in Iowa; although the consultants and sponsors weren't too keen on mentioning it in the guide,

33. Kresensky to Gallaher, 1 February 1937, FWP files, SHSI.

34. Kresensky to Gallaher, 5 April 1937, FWP files, SHSI. 
Kresensky agreed with the editor that young men and boys in Iowa "spend a great deal of time around pool halls." ${ }^{35}$

Ruth Gallaher had in fact commented on the implication in an early draft "that only farm boys patronize the pool halls. This is not intended, I am sure." Of greater concern to Gallaher was the lack of attention given in the essay to pioneer sports and recreation. She also suggested including not just the masculine pursuits of horse racing, foot racing, and log rolling, but traditionally feminine activities, such as quilting and husking bees, singing schools, and spelling contests. Despite her suggestions, the final essay deals almost exclusively with 1930s recreational pursuits, including visits to the beer parlor and pool hall (by many lowans, not just farmers). Generally, though, Gallaher's recommendations were taken very seriously. ${ }^{36}$

Gallaher was most useful on matters of historical accuracyshe seemed able to recall innumerable facts about Iowa history on demand. She offered three pages of detailed, point-by-point criticisms of factual inaccuracies in the history section of the guidebook manuscript. Gallaher was a great help to Kresensky, but her historian's obsession with accuracy must have grated at times on his poetic sensibilities. She also contributed to the snail's pace of the guidebook's production, because she refused to let her criticisms stand in for actual approval of the manuscripts, since her corrections had not been verified. That meant that when the State Historical Society of Iowa agreed in the spring of 1937 to sponsor the guidebook, the society still wanted to see the entire manuscript before approving it, something that would take months longer than expected.

The difficulties of obtaining accurate and authentic material were exacerbated by the controversial nature of some of the material, an issue that came to the fore after the publication of the Massachusetts guidebook in the summer of 1937. Soon after it was released, the Boston Traveler revealed that "the book was loaded with political dynamite." According to Jerre Mangione,

35. Kresensky to Gallaher, 16 February 1937, FWP files, SHSI; Kresensky to Cronyn, 1 October 1937, box 14, Editorial Correspondence, FWP Records, NA. 36. Gallaher to Kresensky, 4 February 1937, FWP files, SHSI; WPA Guide to 1930s Iowa, 119-23. 
the coordinating editor of the FWP, a reporter discovered that "while the 675-page book described the Boston Tea Party in nine lines and the Boston Massacre in five, it devoted forty-one lines to the Sacco-Vanzetti case." The book had, up until this "revelation," aroused no objections whatsoever. But even those who initially praised the book suddenly wanted nothing to do with it. The Traveler article set off the anti-New Deal press and put FWP officials on the defensive. The governor of Massachusetts was urged to order the book off the shelves, and anti-New Dealers demanded a "purge of Communist WPA writers." ${ }^{37}$

When the Des Moines Register printed an article about the scandal, Benjamin Shambaugh, the superintendent of the State Historical Society of Iowa (who still hadn't seen the Iowa guidebook manuscript), wrote Kresensky a brief note: "You have doubtless noted the criticism of the Massachusetts Guide which is now in press. The news item concerning the criticism appeared in the Des Moines Register on Friday morning, August 20, on page 7." Shambaugh said nothing more besides "Very sincerely yours," but his point was clear. Kresensky thanked Shambaugh for "calling [his] attention to the news item" and assured him that there was no danger of a repeat incident in Iowa. ${ }^{38}$

Confident as he was about his staff's sensitivity to controversial material, Kresensky became very careful after the Massachusetts incident, particularly concerning material on labor and social welfare. Staffers Ray Cork and John Westburg wrote a lot of material on Iowa labor, but very little of it made it into the guidebook. Some of it may have been deemed inappropriate; there may simply have been too much material; or it may have been intended for places other than the guidebook (Westburg's pieces were used in a newspaper series in the Iowa Federationist, for instance). And some of the writing is simply of poor quality. But Kresensky or other Iowa editors probably censored Ray Cork's pieces on labor - which contained such statements as "Laws are sought to restrain the rich, the powerful, and the greedy. These are in the interests of the poor, the weak, and the

37. Mangione, The Dream and the Deal, 217.

38. Shambaugh to Du Von, 4 May 1937; Shambaugh to Kresensky, 21 August 1937; Kresensky to Shambaugh, 23 August 1937, FWP files, SHSI. 
hungry" - before they ever left the office. John Westburg's pieces, which seem to have been intended expressly for the Iowa Federationist, also have an anticapitalist tone. The final two-and-a-halfpage section on labor in the guidebook focuses on labor legislation and the history of labor organizing, with nothing that could be considered controversial other than a reference to a rarely enforced section of a 1919 criminal syndicalism bill that construed "the display of a red flag, banner, pennant, or badge . . . as inciting to insurrection and an insult to the United States flag. ${ }^{\prime \prime 39}$

Politics are also subdued in the "Agriculture" essay. In correspondence with Washington editors, Kresensky could not keep from expressing his feelings on the subject, but the guidebook's prose is measured, describing the plight of farmers, but avoiding any politics other than a pro-New Deal position. As a man who had grown up in a farming community and had made farmers and small-town people the subject of most of his writing, Kresensky had particularly strong feelings about the "Agriculture" essay. He was not necessarily trying to inject his own politics into the essay, but he did want it to be accurate. When a Washington editor changed "1934 and 1936" to "1934-1936" in the essay draft, Kresensky responded as though personally insulted. "There were not three years of drought but only the two we list," he informed George Cronyn. Insisting that Iowa "is NOT the dust bowl," Kresensky went on to explain his concern about this error:

The farmers' worst enemies are not droughts nor plagues, but bankers, exploiters and economic tyrants. Even the liberals try to cover this up by changing the subject to droughts, chinch bugs, and other plagues. I simply explain this because it seems to me some editorial criticism, comment and suggestion from your office seems to indicate we are associated with the areas west of us. ${ }^{40}$

39. WPA Guide to 1930s Iowa, 99. Kresensky's note to Gallaher asking for comments on one of the essays noted that it "might have material construed as controversial. I would like your comment, especially, on the labor section. All of the material is taken from authorized sources, mainly Iowa laws." Kresensky to Gallaher, 27 September 1937, FWP files, SHSI; Ray H. Cork, "The Objective of Labor Unions," typescript, p. 2, box 4, FWP files, Special Collections, University of Iowa Libraries, Iowa City. Westburg's Federationist series is there as well.

40. Kresensky to Cronyn, 23 September 1937, box 14, Editorial Correspondence, FWP Records, NA. 
If Henry Alsberg and George Cronyn had looked at a few old issues of Hinterland, they would have seen how strongly some Iowa writers felt about farm issues, and about the reasons farmers in the state were suffering and becoming militant in the early 1930s. Kresensky's essay in an early issue of Hinterland's first series (1934) indicated his sympathies for farm militancy; at the same time, it demonstrated that his own (and many other Iowans') "radical" tendencies were less Marxist than they were anticapitalist Jeffersonian. That Kresensky made such a forthright statement about "bankers, exploiters and economic tyrants" in a letter to his federal superiors is jolting, but his passions on some issues compelled him to speak out.

Kresensky's Hinterland piece, "Is Milo Reno a Red," replayed the militant farm struggles of 1932, when farmers' strategies evolved from the peaceful methods of withholding their produce from markets (under the National Farm Holiday Association's orders) to what seemed to some people like open warfare. Farmers picketed, rioted, resisted mortgage foreclosures, and sometimes actually drove away mortgage agents. Because Milo Reno, the moving force in the Farmer's Union and president of the National Farmers' Holiday Association, was believed to be a leader in the revolution, wrote Kresensky, he was branded "agitator, bolshevist, Red, bum, employee of the Russian Soviets, radical." Kresensky rejected this characterization. "In all his talks he uses the ideology of a Jeffersonian Democrat. His ideal is a free, independent farmer, owning his land, a small capitalist as it were. He would not want the farmers either socialized (collectivized) or peasantized." Reno's ideal was the Grange, not Soviet-style, collective farms, said Kresensky. And his support of violence, when necessary, was "not on the ground of revolutionary tactics, but on the ground that the American patriots back in 1776 did the same." In Kresensky's eyes, Reno exemplified "respectable Americanism." ${ }^{11}$

Kresensky thus demonstrated a position typical of midwestern radicals, one that did not rule out Marxism but that more often looked to native traditions to justify beliefs and actions.

41. Raymond Kresensky, "Is Milo Reno a Red?" Hinterland, 1st ser. 1 (n.d.), 21-25. 
Douglas Wixson maintains that midwestern literary radicals tended to be antiideological, drawing on a range of political and intellectual traditions (from Debsian socialism to the Grange to populism) to understand and cope with current conditions. ${ }^{42}$ In Iowa, progressive regionalist writers saw themselves as advocates for issues fundamentally linked to national well-being. Farmers were the backbone of America, they believed; therefore troubles facing Iowa farmers were national problems. Other Hinterland contributors who worked for the FWP in Iowa, such as Opal Shannon, expressed in poetry the frustration and anger of hard-working farmers, who "love and serve the greedy land" but see few rewards for their labor. Her poem, "Folk Moot," documents a "ferment" among farmers. ${ }^{43}$

Men -

Faces scarred with the years

Of land service.

Hands knowing the feel

Of sodden corn husks

In a wet dawn,

The suffocating ache

Of dust-clogged lungs;

The weariness that

Stretches to infinity...
Here they have gathered

To sit in a huddle

On wobbly benches

Or stand in groups

Beneath the lantern flare:

Planning -

Reasoning;

Rebelling!

There's a ferment working.

Occasional but very powerful images of "ferment" and rebellion in Hinterland have only subdued parallels in the Iowa guidebook, which reveals political preferences only through open support for the New Deal. Despite Kresensky's own predilections and sympathies, as well as those of many on his staff, Kresensky acceded to the request of Ray Murray, Iowa's Secretary of Agriculture, that Reno's name be left out of the agriculture essay since he was such a controversial figure. Yet the essay does contrast a widely held pastoral image of Iowa with the reality of farm tenancy. Thus the essay as it appears in the guidebook is, like so many other guidebook essays, a compromise. ${ }^{44}$

42. Wixson, Worker-Writer in America, 149.

43. Hinterland, 1st ser. 1 (January 1936), 6.

44. Murray to Kresensky, 14 February 1936, box 12, FWP files, Special Collections, University of Iowa Libraries. 
The essay opens by presenting facts and figures that emphasize the importance of agriculture in Iowa, noting that all but three of Iowa's counties were considered "agricultural." It gives figures for the number of farms $(221,986)$, their combined acreage $(34,459,000)$, and the percentage of Iowans working in agriculture (more than a third of the state's 'gainful workers'). Following this is a snapshot of Iowa as home to the yeoman ideal - on the surface: "The panorama is of corn, growing in great square and rectangular fields, of grain ripening in the prairie winds; of grazing cattle, red barns, tall silos, white farmhouses; and of towns bordering the highway at regular intervals and dominated by grain elevators and church spires. The bird's-eye view shows a land of independent farmers of rich soil, and prosperity. Closer examination, however, reveals another aspect." This description is followed by the results of the report of the President's Committee on Farm Tenancy, which found tenancy rates on Iowa farms to be on the rise, and to be significantly higher than the national average. Farm owners, too, were burdened with high mortgages. "Insecure tenure, whether of tenant or owner, is good neither for the farmer nor for the land," the guidebook notes. "The insecure family moves frequently, the children suffer from lack of continuity in their schooling, and the family is deprived of normal social contacts." Each February "trucks and wagons crowded with furniture rumble over the frozen roads. . . Load after load jolt past the farm houses, stretching out like a gypsy caravan going on to camp elsewhere for a brief time ... hoping that the new farm will be a little better than the last one." The land also suffers from the farmers' instability, the guidebook notes. Farmers engage in practices designed to get as much as they can out of the land as quickly as possible, robbing the soil of fertility and causing erosion. ${ }^{45}$

In this sad narrative, as in Pare Lorenz's WPA film, The Plow that Broke the Plains, which dramatically portrays the plight of "poor land and poor people," the programs of the New Deal, particularly the Agricultural Adjustment Administration, play a heroic role, as do the people of Iowa and their culture. The essay titled "Iowans: The Social Pattern" notes that "a success- 
ful experiment in living, based on the fusion of agricultural and industrial forces, may possibly be carried out here, in this fertile middle-ground between the congested districts of the East and the more sparsely settled West. Iowa has the opportunity-rich land, remarkably uniform diffusion of the population, traditions of culture and tolerance. ${ }^{\prime 46}$

Kresensky and his Hinterland colleagues were clearly not radical revolutionaries, but having Hinterland as an outlet may have made it possible to keep politics (other than pro-New Deal politics, that is) out of the guidebook. And aside from the Iowa editors' self-censorship, they had careful readers who were alert to political bias. Well before the Massachusetts incident, readers such as Gallaher had already been paying close attention to the issue; in fact, her reading tended to be even more critical of the essays' content than Washington's. The "Iowans" essay is a case in point. The correspondence about that essay also illustrates the Washington office's habit of wavering in its approval of certain essays.

Originally subtitled "The Contemporary Scene," the "Iowans" essay was meant to be, in Kresensky's words, "a sort of lead to all the essays in the book." The challenge of the essay was to encapsulate Iowa and Iowans in broad brush strokes, in a way that would be evocative but not inaccurate. Gallaher read the essay and noted that Kresensky and his staff had "brought out the most important characteristics of Iowa," but, since he wanted suggestions, she felt compelled to make several points. She questioned the writers' explanation of Iowa's shift from the Republican to the Democratic Party, and argued that what the writers considered as Iowans' commitment to equality was really only a commitment to equal opportunity. Perhaps calling Kresensky on his own political biases, she added, "neither am I certain that all educated Iowans are liberals, whatever that may be. Perhaps you mean to imply that conservatives are not educated. Iowans have, on the whole, always stood for a fair deal, which is my idea of equality." ${ }^{17}$

46. Ibid., 30 .

47. Kresensky to Gallaher, 5 February 1937; Gallaher to Kresensky, 11 February 1937, FWP files, SHSI. 
The more politically pointed of Gallaher's comments took Kresensky by surprise, since the Washington office, "strangely," seemed "quite satisfied" with the essay. "However," he added, "I shall incorporate your suggestions for I do not believe the other office really knows the state." They also apparently didn't really know their own minds, because eighteen months after approving the "final" draft of the essay, after Ruth Gallaher had given her final approval, and after the essay had gone into galley form, a WPA administrator read the galleys and found the essay "a little remote and cold" and "lacking in spirit for an opening essay." Alsberg sent a last-minute letter to Kresensky, giving him a week to rewrite the piece. Alsberg complained that the essay "suffers from lack of immediate knowledge of the country and its people." To correct this "sense of remoteness," he advised Kresensky to "add concrete examples and light touches" that give a more vivid picture of life in the state. "Your knowledge of Iowa and Iowans and your talent for lyric writing should have happy expressions in this article," Alsberg added. "The book, as a whole, is pretty good, and we are anxious to have the best possible introduction to it. . . . Do what you can with it and don't be afraid to show originality and enthusiasm." ${ }^{\prime 48}$

By this time, Kresensky simply could not muster any enthusiasm for further revisions. He refused to make any more changes, not only because he, his staff, and the sponsors were satisfied with the essay's portrait of Iowa and were anxious to get the book finished, but also because the essay had finally met with Gallaher's approval. The Washington office acceded to Kresensky's wishes, but insisted that the essay's title and position in the book be changed, since it failed to really describe the 'contemporary scene' or to properly introduce the book. Thus "Iowans: The Social Pattern" is the second essay in the guidebook, following the "Natural Setting." This change may have pleased Kresensky anyway, since he had earlier confessed to Gallaher that the "Natural Setting" essay was his favorite.

48. Memo from Henry Alsberg to Mr. Woodward, 22 July 1938; Alsberg to Kresensky, 6 July 1938, box 14, Editorial Correspondence, FWP Records, NA. 
Whether it worked any better than the "Iowans" essay as an introduction to the guidebook is another question. ${ }^{49}$

Through it all, Kresensky somehow retained his enthusiasm about the guidebook itself, telling congregations about it when he served as a visiting minister or gave poetry lectures at vespers services. Apparently he had come to terms with all the ways in which the book fell short. The walking on political eggshells, self-censorship, consultation, and careful editing, considered alongside the kinds of views and images present in Hinterland, suggest a conscious decision on the part of Kresensky and other Iowa editors not to tell, or to tell completely, the 'authentic' story of Iowa, for fear of another "Massachusetts incident" that would damage the Writers' Project and the guidebook's sponsor, the State Historical Society. The story finally told represents at best an imperfect compromise, as the negotiations over the "Iowans" essay showed. In the end, the guidebook was an achievement in Kresensky's eyes because it was not only useful, but also because it might inspire non-Iowans and Iowans alike to discover and rediscover the back roads, legends, plants, animals, architecture, art, literature, and traditions of Iowa. Kresensky's enthusiasm about the completed guidebook was warranted. When it finally was released in August 1938, readers saw the book's strengths and tended to overlook its flaws. ${ }^{50}$

IOWA: A GUIDE TO THE HAWKEYE STATE was widely reviewed and well received. Reviews appeared in newspapers ranging from the Des Moines Register to the San Francisco Chronicle, the St. Louis Post-Dispatch and the New York World Telegram; and in magazines and journals ranging from the Iowa Journal of History and Politics to Frontier-Midland and even Iowa Bird Life. Writer Jack Conroy, a friend of Kresensky, arranged for reviews in a number of left-wing outlets, including the Progressive Weekly,

49. Alsberg to Woodward, 22 July 1938; and Alsberg to Kresensky, 6 July 1936, box 14, Editorial Correspondence, FWP Records, NA; Kresensky to Gallaher, 3 February 1937, FWP files, SHSI.

50. Kresensky to Shambaugh, 16 November 1937, FWP files, SHSI. 
New York's Sunday Worker, Chicago's Midwest Record and the San Francisco People's World. ${ }^{51}$

Ware Wimberly wrote in the Christian Century that Iowa's guidebook "reveals a story with which all Iowans, and all patriotic Americans, for that matter, ought to be familiar." Phil Stong reviewed the guidebook for the New York Herald Tribune and the Saturday Review of Literature. In the Saturday Review he disregarded the book's collective authorship and asserted that "Mr. Kresensky has gone to the right places, talked to the right people, and done a superb job in the text, pictures and production." In Stong's opinion, the guidebook brought out all of the most pertinent and fascinating information about Iowa. "We have had mound-builders and Sioux, a superior bunch of Atheists who tried to start a community ... the spick and span little Dutch shoe town of Pella which produces the best ham known to man ... De Soto and La Salle, the only president born west of the Mississippi, practically all the secretaries of Agriculture - all named Wallace - the Mormon hegira, Black Hawk and Keokuk, Lillian Russell, Dvorak ... the first state fair in America ... and anything else you would care for in the way of history, romance or statistics." In disregarding (or not recognizing) that every page of the guidebook represented the work of at least ten people, Stong was, in effect, saying that the product, not the process, was what counted. And he liked the product. ${ }^{52}$

But some criticism of the guidebook did come, even from one of its own contributors. Don Farran complained in a 1973 reminiscence that the guidebook ought to have offered a more critical portrait of the state. He insisted that "the political hand of Washington had lain heavily on the material. Nowhere in the material was there intelligence concerning who really framed and passed the state's legislation; which period of the state's life

51. Reviews listed in correspondence from Kresensky to Alsberg, 7 and 19 December 1938, box 13, Editorial Correspondence, FWP Records, NA.

52. Ware Wimberly review quoted in "The Federal Writers' Project of the Works Progress Administration," a booklet describing the FWP program, [1939?], in box 4, Tjernagel Papers, State Historical Society of Iowa, Iowa City; Phil Stong, "The U.S. in the Middle," in Saturday Review of Literature 18 (17 September 1938), 11. 
had been controlled by railroads, which by bankers, which by powerful insurance companies, which by public utilities. ${ }^{.53}$

But most others close to the guidebook's production were pleased with it, including, most importantly, Kresensky. And his colleagues on Hinterland approved as well: Bernice Bergman gave the book a rave review in Hinterland, noting that "even the native Iowan will learn so much about his own state and his home community that he will wonder where he has been all his life not to know these things. ${ }^{\prime 54}$ The Washington editorial hand had lain heavily, but so had Iowa's, and the result was an important achievement, given all the perspectives and compromises it embodied. Iowa: A Guide to the Hawkeye State made a major contribution to the state and nation not so much as a tourbook, but rather as a detailed portrait of the state in the late 1930s and of its history up to that time.

After the guidebook was published, the Federal Writers' Project in Iowa continued many smaller projects, such as county and city histories, a number of which had been published prior to the completion of the state guidebook. Iowa writers and researchers also collected material for national projects, including Hands that Built the Nation and America Eats. State publications planned after the guidebook included, in addition to city and county guidebooks, "Farming Methods" (for use in schools), "Places to Play in Des Moines," a "History of Burlington Legion," "Your Vacation in Iowa," a catalog of Columbia Museum in Dubuque, a literary map of Iowa, a church history, and a rural school history. ${ }^{55}$

Other projects included an "Almanac for Iowans," a history of sports in Iowa, a book of Indian legends, a history of coal mining in Mahaska County, a study of the foreign language press in Iowa, and a book on the Negro in Iowa. Apparently, none of these were published, probably for lack of sponsorship.

53. Farran, "The Federals," 1192-93.

54. Bernice Bergman, review of Iowa: $A$ Guide to the Hawkeye State, in Hinterland, 2d ser. 2, no. 11 (1938), 89.

55. A. E. Michel to Florence Kerr, 4 September 1941, box 1339, "State" Series, 1935-1944, Writers' Program, WPA Central Files, Iowa, RG 69, National Archives. The national projects mentioned were never published. 
A completed draft of "The Negro in Iowa" was sent to the national office in December 1940 for review. Washington editors suggested revisions, but asked whether there was sufficient material to make a book "in a state that in 1920, before a decline in the state Negro population began, had less than 20,000 Negroes." Such discouragement, along with a largely critical view of the text itself, probably convinced the lowa staff to shelve the project. ${ }^{56}$

By the time the "Negro in Iowa" was finished, Kresensky had left the project. Former project member John Westburg speculated that Kresensky left because of political pressure, including hostility from a new Republican administration in Iowa, but never specified what "political abuse" pushed Kresensky into departing from the project. The atmosphere of suspicion surrounding the Dies Committee investigations of the FWP for suspected Communists may have made it too uncomfortable to remain on the project. Or Kresensky may simply have decided to move on, allowing himself more time to pursue his own projects. In any case, when Kresensky left the FWP, both it and Hinterland withered away. The final Hinterland was published in mid-1939. According to John Westburg, after Kresensky left the Project, morale nearly collapsed, and the Project lost most of its vigor and energy well before the FWP was officially terminated in 1942. "The writers who had contributed the most to the Project's productive successes began to abandon the Project, most leaving Iowa never to return," Westburg wrote. Kresensky himself remained in Iowa for the rest of his life, continuing to write, publish, and teach poetry, while working in Younkers department store in Des Moines to support himself.

56. Ibid. See also David McGlaughlin to Kerr, 9 October 1939, ibid. The "Negro in lowa" project, it seems, took about two years to complete. Comments on "Negro in Iowa" from editorial report with manuscript, dated 30 December 1940, FWP files, SHSI. Eight years later, Leola Bergmann's monograph, "The Negro in Iowa," was published in the Iowa Journal of History and Politics, suggesting that there was, in fact, enough material to warrant a study on the subject. Despite the article's title Bergmann never mentions the 1940 study by the same name. She did draw on several WPA county histories in writing her extended essay, but since the 1940 WPA study on "The Negro in Iowa" was never published, Bergmann may not have known about it. 
He also wrote a novel about Iowa small-town life called $A$ Wide Place in the Road, which he was unable to publish. ${ }^{57}$

Hinterland, like the Federal Writer's Project in Iowa to which it was so intimately connected, left a multifaceted legacy. Its political nature brought the FBI calling on several former project workers who had been involved with the magazine. The investigations did not uncover any incriminating evidence, but they did mark the end of an era of federal and popular investment in the dream of a truly public culture. But the progressive regionalism of the 1930s was firmly rooted and tenacious, creating a second legacy, a new era of midwestern regionalism. This post-McCarthy, post-Hiroshima, television-age midwestern regionalism represented a new urge for rootedness and a desire to make the world better, starting locally. The regionalism that reemerged in the late 1960s and 70s, with the North Country Anvil (modeled on Jack Conroy's Anvil of the 1930s) published in Minnesota, and the North American Mentor, independently published by former Iowa project worker John Westburg in Iowa and later in Wisconsin, was firmly grounded in the midwestern literary radicalism and "progressive regionalism" of the 1930s. Several issues of the Mentor are dedicated to celebrating the life and work of Raymond Kresensky, and Westburg spent his last years compiling Kresensky's poetry for publication. Foolkiller in Kansas City and North Dakota Quarterly have openly acknowledged their debts to an earlier generation of radical midwestern writers, and Midwest Cultural Conferences have been held in Kansas City and Minneapolis. ${ }^{58}$

57. Westburg, "Raymond," xxi; Jim McGovern (a nephew of Kresensky's), interview with author, 27 January 1996, St. Paul. Bob Kraus (another nephew) provided a copy of Kresensky's novel.

58. Dale Kramer noted in a letter to Meridel Le Sueur in 1955 that he had been questioned by the FBI about Du Von, at that point a bureaucrat of some stature, according to Kramer. "I gave it as my opinion that Jay was trying too hard to climb up in the government to think about overthrowing it." Box 3, Meridel Le Sueur Papers, Minnesota Historical Society, St. Paul. Lee ver Duft, a writer on the Iowa Project to whom Kresensky had been a mentor, wrote a poetic tribute to Kresensky in 1976 titled "Epistle to a Poet, Bound, But Outer" a section of which (p. 3) reads: "-Came the McCarthy scandal then;/ recochets [sic] to the Hollywood Ten:/ and the FBI came calling on us one by one,/ to ascertain whether some project grudger would talk/ got no tainted testi- 
Iowa: A Guide to the Hawkeye State lives on as well, reprinted for the second time in 1996 by Iowa State University Press under the title The WPA Guide to 1930s Iowa. Single-author attempts to update the guide have not significantly improved on it. How could they? All the technological advances of the past fifty years cannot make up for the combined efforts of fifty to sixty women and men in the 1930s who discovered and recorded information not readily found on computer databases or in encyclopedias, information gleaned from taking long drives in slower cars, observing, talking to people who remembered as far back as the Civil War, and digging through attics and archives.

Iowa's WPA guidebook could not have been written without the major federal program that supported it. And neither the FWP nor the WPA as a whole would have come into existence without the widespread unemployment of the Great Depression. The broader cultural climate of the period is indelibly played out in the pages of the guidebook, often in subtle ways. The Midwest Literary League and Hinterland, both poorly documented and now largely forgotten, represent aspects of Iowa cultural and intellectual life of the 1930s that are not outwardly present in Iowa's WPA guidebook, but they certainly added meaning to the lives of those who created it. Their regional commitment, and the ways it related to the administrative and bureaucratic context in which they worked, played key roles in the production of the guidebook.

mony from any one - / safe to join the Civil Liberties Union ... ?" Poem provided to author by Helena Dodds, Lone Rock, Iowa. In a tribute to Tom McGrath, in North Dakota Quarterly 50 (Fall 1982), 5-7, Fred Whitehead's introduction mentions Midwest Cultural Conferences in Kansas City and Minneapolis. 
Copyright of Annals of Iowa is the property of State of Iowa, by \& through the State Historical Society of Iowa and its content may not be copied or emailed to multiple sites or posted to a listserv without the copyright holder's express written permission. However, users may print, download, or email articles for individual use. 